$2013 / 3$

\title{
Energy Efficiency Improvement Potential in Historical Brick Building
}

\author{
Andra Blumberga ${ }^{1}$, Gatis Zogla ${ }^{2}$, Kristaps Zvaigznitis ${ }^{3}$, Dagnija Blumberga ${ }^{4}$, Marija Burinskiene $\dot{e}^{5}$, \\ ${ }^{1-4}$ Riga Technical University, ${ }^{5}$ Vilnius Gedeminas Technical University
}

\begin{abstract}
Energy efficiency in historical heritage buildings is viewed as a taboo because these buildings usually are protected under law and no energy efficiency measures that would change the appearance of the building are allowed. In this paper we look at the potential of increasing energy efficiency level in historical buildings. Measurements to determine energy efficiency of a historical brick building have been done, which also give the possibility to determine the potential of energy efficiency measures in this building.
\end{abstract}

Keywords - Energy efficiency, historical heritage, historical buildings, innovative insulation materials.

\section{INTRODUCTION}

It is hard to increase energy efficiency level in historical brick buildings. These buildings usually are protected by law and no energy efficiency measures are allowed that change the appearance of the building [5]. The largest energy savings in buildings can be achieved by insulating outer walls and changing windows. If change of windows in historical buildings might be permitted, then wall insulation from the outside is prohibited.

Since the low energy efficiency of historical brick buildings in Latvia basically is protected by law, there has practically been no research to determine the existing energy consumption of these buildings. Some research has been done to determine the energy efficiency level, energy efficiency potential and measures in historical brick buildings outside Latvia. Fabrizio Ascione et.al. [1] conducted research to investigate energy retrofit possibilities of historical buildings in Italy. This study suggested to use thermal plaster for insulation. Said M.N.A et. al. [2] researched how internal wall insulation affects hygrothermal performance of a masonry wall. E. Grinzato et.al.[3] have used thermography for investigating historical buildings. This gives possibility to assess the moisture and thermal diffusivity of walls in historical buildings. All previously mentioned research is concentrated on one building analysis, which does not show the existing energy efficiency level of historical buildings. The existing energy efficiency level in historical buildings has been investigated in research of Kristian Fabbri et.al. [4], where they use EPC (energy performance certificates) to classify historical buildings. Nonetheless, no extensive research has been done to determine the existing energy consumption in historical buildings, which is the first step to understanding the energy efficiency potential of historical buildings.
Research was done in order to understand the potential of energy efficiency in historical buildings. Measurements and energy efficiency measures were implemented in a historical small size building in Riga, Latvia. A small size building was chosen because this gave a possibility to implement more energy efficiency measures with the available resources. This research was done as part of Baltic Sea Region Programme 2007 - 2013 project "Co2ol Bricks".

\section{EXISTING SITUATION}

The building is located in Riga city in Spīkeri complex, the industrial aesthetics of which is included in the UNESCO World Heritage List. The building has an area of $56,3 \mathrm{~m}^{2}$. The building is currently empty and is not being used, but previously the building housed WC facilities.

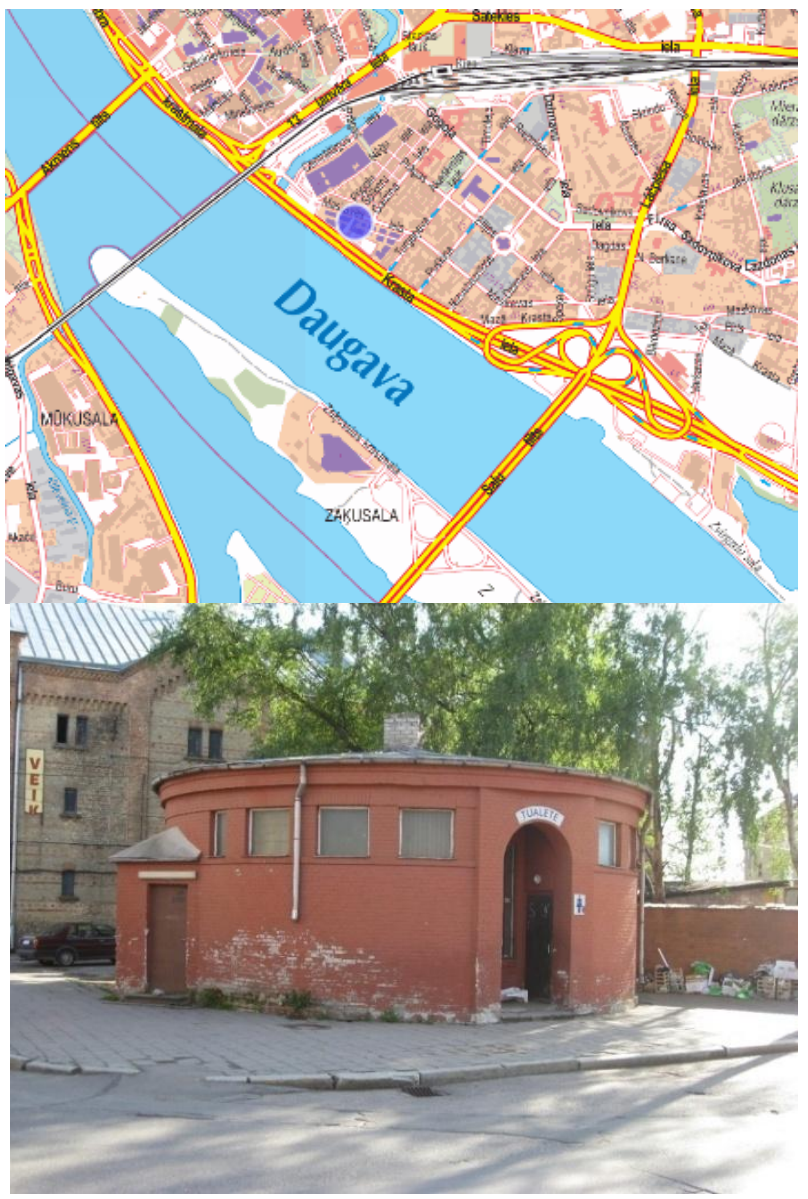

Fig. 1. Building Maskavas iela 8, Riga, location and facade 


\section{A. Building envelope}

Exterior walls of the building are made of painted silicate bricks with a thickness of $51 \mathrm{~cm}$ and an area of $129,13 \mathrm{~m}^{2}$. The building is uninhabited for several years and its construction is significantly affected by weather and human factors.

Construction damage above the window was observed, indicating potential moisture penetration from the roof. The damage reveals deeper, unpainted bricks which, opposed to the bricks on the surface, have not formed a surface layer over time, so they are more rapidly exposed to moisture damage. The wrong design contributed these defects, because there are no lintels. All the bricks are immured in parallel vertically and without complying with the required angle. Damage is observed at the bottom as well, where the gutter is not at the required angle and, as a result, rain water leaks into the walls. At the top left moss growth is observed, leading to intensifying of brick deterioration.

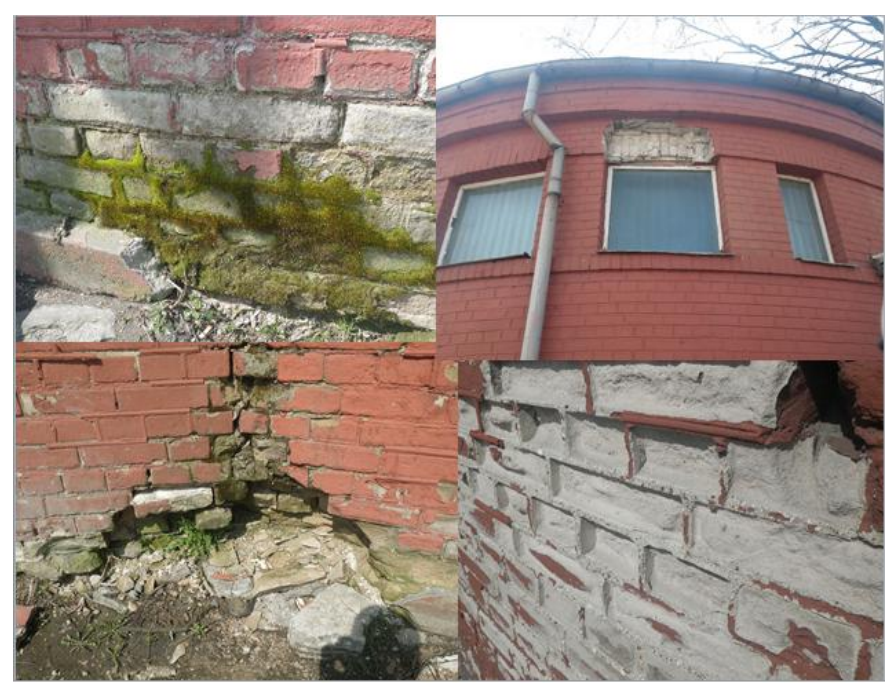

Fig.2. Damaged building envelope elements

The final parts of building gutters are missing, and due to this, water is not drained $20-40 \mathrm{~cm}$ above the ground as recommended, but about 160 to $220 \mathrm{~cm}$ in height. One of the building windows has been replaced with plywood, which is not suitably fixed. At the bottom of Figure 2, damage to the construction of the wall is visible, where the whole bricks are missing and the stitches crumbling away. Damages can be observed up to a height of $2 \mathrm{~m}$ on the annex joint.

The top and final leg of gutter is missing, which results in moisture draining into the wall. At the bottom of the picture moisture damage to the building's foundations can be observed and on the right of the picture -- part of the joint has fallen out.

\section{B. Estimated building energy consumption}

Since the building has not been used in the last years, no measured energy consumption data is available. Therefore calculations were done to determine the building's space heating energy consumption. Calculations were done according to Cabinet of Ministers Regulation Nr. 39 "Method for calculating energy performance of buildings" [7]. This method is based on ISO standard 13790:2008 "Energy performance of buildings. Calculation of energy use for space heating and cooling" [8].

Measurements were also done to determine the heat transfer coefficient of the outer walls.

Since there are many unclear parameters (internal heat gains, usage characteristics of the building, air change rate, etc.) that have to be taken into account in the calculations, the accuracy of calculations is quite low. It is estimated that the accuracy of the calculated space heating energy consumption is $\pm 20 \%$. In many cases such a calculation error would be considered to be very large but in case of this building, it is normal.

The building does not have a mechanical ventilation system, so the building has a natural ventilation system with air flow through the building envelope. The air exchange in the building was set based on the type of building windows, and it was assumed as $0,5 \mathrm{~h}^{-1}$ during the heating period.

TABLE I

BUILDING ENVELOPE

\begin{tabular}{|l|c|c|c|c|}
\hline \multicolumn{1}{|c|}{ Envelope } & $\begin{array}{c}\text { Area, } \\
\mathbf{m}^{\mathbf{2}}\end{array}$ & $\begin{array}{c}\text { Heat transfer } \\
\text { coefficient, } \\
\mathbf{W} / \mathbf{m}^{\mathbf{2}} \mathbf{K}\end{array}$ & $\begin{array}{c}\text { HT (UA), } \\
\mathbf{W} / \mathbf{K}\end{array}$ & MWh/year \\
\hline External walls & 129.13 & 1.48 & 191.1 & 16.76 \\
\hline Roof & 80.12 & 1.00 & 80.12 & 7.03 \\
\hline Windows & 16.20 & 2.80 & 45.36 & 3.98 \\
\hline $\begin{array}{l}\text { Floor to the } \\
\text { bottom }\end{array}$ & 80.12 & 0.80 & 64.09 & 5.62 \\
\hline Total & & & $\mathbf{3 8 0 . 7 5}$ & $\mathbf{3 3 . 3 9}$ \\
\hline
\end{tabular}

The calculated energy consumption for space heating that includes heat conduction losses, heat losses through ventilation and internal and solar heat gains for this building on Maskavas iela 8 is $672 \mathrm{kWh} / \mathrm{m}^{2}$ per year $(37.93 \mathrm{MWh}$ per year). This is very large energy consumption for space heating compared to the average building in Latvia which is $150-180$ $\mathrm{kWh} / \mathrm{m}^{2}$. However the building at Maskavas 8 cannot be compared to an average building because the heated area of this building is only $56,3 \mathrm{~m}^{2}$, which is far less than an average building. The smaller the building, the bigger the specific energy consumption because the specific area of the building envelope is bigger for smaller buildings. The height of this building is also bigger than the average building. All these factors lead to very large space heating consumption.

\section{MEASUREMENTS OF HEAT FLUX IN WALLS}

During the measurements heat flux in brick walls was measured and heat transfer coefficient was calculated. Before the installation of heat flow density measuring equipment, measurement sites were surveyed with the help of a thermocamera, to make sure that the measurement point does not contain thermal damage, which could reduce the accuracy of measurement.

Heat flux measurements were done in two places at the same time. All measurements of heat flux and calculations for determining heat transfer coefficient of the walls were done according to ISO standard 9869:1994 "Thermal insulation. 
Building elements. In-situ measurement of thermal resistance and thermal transmittance" [9].

Measurements have 10 minute time step. Figure 4 shows more than 11 days of measurements. During the measurements the building was heated with two $2 \mathrm{~kW}$ electrical heaters that were put to operate all the time with a constant heat output (4 $\mathrm{kW})$.

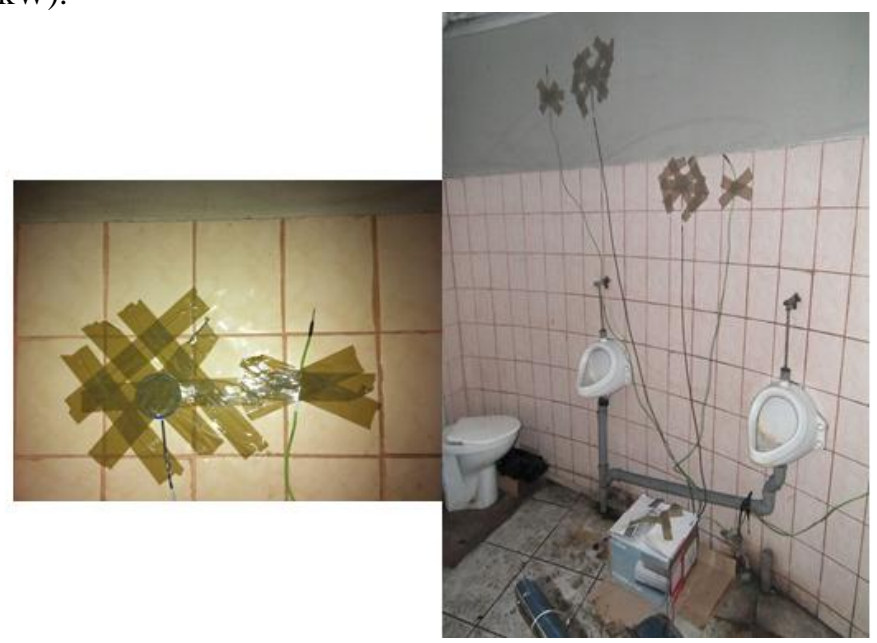

Fig.3. Heat flux measurements at Maskavas 8

Figure 4 displays instantaneous heat transfer coefficients of the walls of Maskavas iela 8. These measurement data, together with outdoor and indoor air temperature data, were used to determine heat transfer coefficient of the walls.

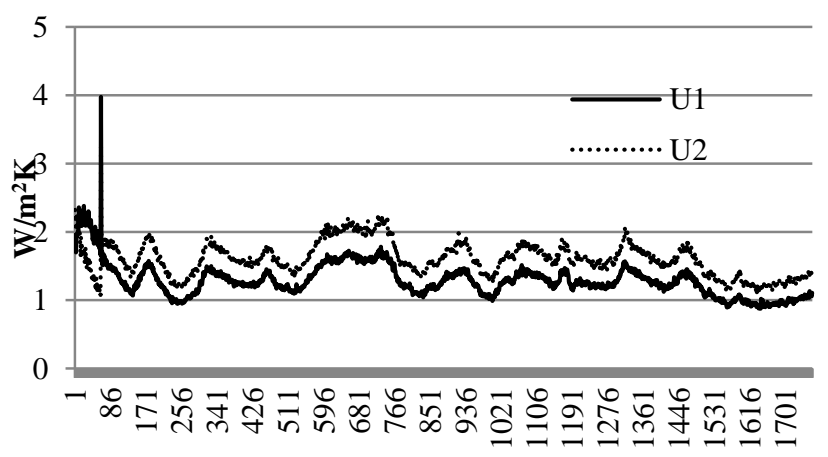

Fig. 4. Instantaneous heat transfer coefficients of the walls of Maskavas 8

As can be seen from the figure, the measured heat fluxes were not the same but different. This means that heat transfer through the outer walls is the same in the entire façade. The changes in heat transfer throughout the wall lead to believe that different parts of the walls have suffered different damage from water, ice thawing, air pollution. This also is supported by visual inspection of the building from outside what was examined above in this paper.

Measured heat transfer coefficient was in the range from 1.3 to $1.6 \mathrm{~W} / \mathrm{m}^{2} \mathrm{~K}$. The average heat transfer coefficient was calculated to be $1.48 \mathrm{~W} / \mathrm{m}^{2} \mathrm{~K}$. Measured heat transfer coefficient of outer walls is higher than the calculated heat transfer coefficient for $51 \mathrm{~cm}$ thick silicate brick wall.

\section{A. Measurement of moisture content}

Nondestructive moisture content measurements were made by the dielectric moisture indicators Trotec 600 and 650 . Using these devices moisture content in the wall can be determined qualitatively in a scale from 0 to 200 . If the measured moisture is less than 40, the building material is dry, if between 40-80 - humid, and if more than 80 sections - wet.

Measurements were made on the interior walls of Maskavas iela 8 in six different locations. Measurement data are collected in Table II.

TABLE II

Nondestructive Moisture Measurements at Maskavas IELA

\begin{tabular}{|c|c|c|}
\hline & 5 cm depth & 30 cm depth \\
\hline 1. & 57,5 & 35 \\
\hline 2. & 61,6 & 45 \\
\hline 3. & 64,3 & 50,9 \\
\hline 4. & 107 & 30,3 \\
\hline 5. & 139,4 & 37,6 \\
\hline 6. & 141,3 & 40,5 \\
\hline
\end{tabular}

Measurements showed that the moisture in the wall has penetrated in the shallow depths (up to $5 \mathrm{~cm}$ ). The deeper layers of the wall are dry. This correlates with our research done by modeling moisture content of brick walls for similar building in Riga at Kronvalda blvd 1 (see Fig.5).

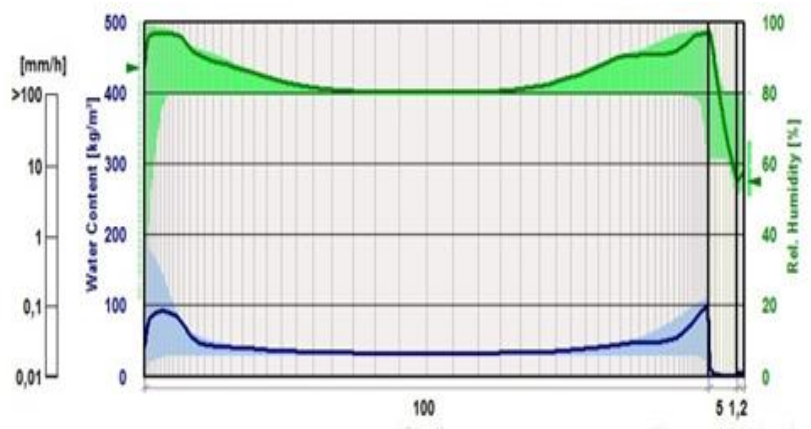

Fig. 5. Moisture content modeling for brick wall that is insulated from inside with rock wool

Moisture content modeling of a similar building was done with software WUFI, which is used worldwide for modeling moisture penetration in building envelope. In Figure 5 it can be seen that relative humidity and water content of the wall throughout the year varies a lot on both the inner and other surfaces of the wall, but in the middle part -- humidity and moisture content practically does not change and is constant. Moisture can penetrate walls only if walls have cracks, brick deterioration or other damage that can be seen with the naked eye.

Moisture content measurements with destructive method of walls in the six places, where nondestructive measurements were done, were also made. Destructive methods are more precise than nondestructive methods. In this case it was chosen to drill holes in the walls and measure moisture content by weighing wet and dry brick dust. Brick dust was dried in a 
drying oven until there was no change in the mass of the sample.

Unfortunately these measurements just showed that this method cannot be used for determining moisture content in bricks due to the heating up of the drill during drilling. The temperature of the drill during drilling exceeds $150{ }^{\circ} \mathrm{C}$. This is enough to remove part of the moisture of the brick even before drying the brick dust in the oven. There is a need for creating new techniques for determining and quantifying the moisture content of bricks in building walls.

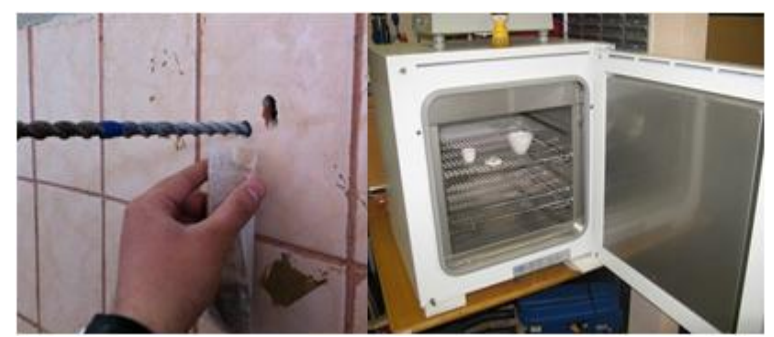

Fig. 6. Drilling and collecting of brick dust and the drying oven used for drying brick dust

\section{B. Determination of water-soluble salts}

To determine water-soluble salts, a qualitative test method based on the methods developed in „A laboratory manual for architectural conservators" by International Centre for the Study of the Preservation and Restoration of Cultural Property (ICCROM) was used. Small pieces of bricks were taken, crushed and immersed in water and tested with indicator paper (see Figure 7). A quantitative analysis of sulfate was carried out using the ,determination of barium in a form of barium sulfate" methods.

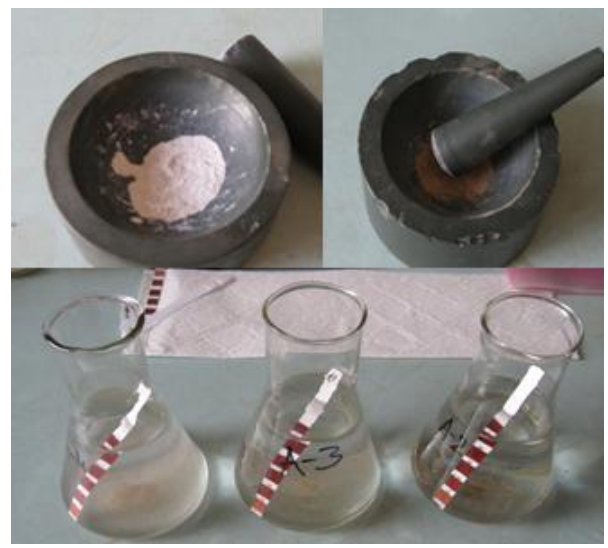

Fig.7. Qualitative water-soluble salt test method

It was determined that the sample contains $2,5 \mathrm{mg} / \mathrm{NO}_{3}{ }^{-}$ and minimal amount of $\mathrm{SO}_{4}{ }^{2-}$ that can be caused by acid rains, sulfates may also form in brick burning process.

\section{ENERGY EFFICIENCY MEASURES}

Energy efficiency measures in the historical building at Maskavas iela 8 present different possibilities for implementation of renovation by use of different insulation materials for exterior walls applied from inside.
Insulating materials, which are suitable for exterior wall insulation from the inside suggested in Table III.

Selection of insulation materials depends on two main criteria stated for energy efficiency improvement project:

- Level of energy saved. Calculations show that the best results for reduction of heat consumption could be reached by use of vacuum insulation panels $-285 \mathrm{kWh} / \mathrm{m}^{2}$ year.

- Reduction of inside area. Calculations show that the best results to reach minimum reduction of inside area by installation of inside insulation for reduction of heat consumption could be reached by use of aerogel insulation - thickness only $0,04 \mathrm{~m}$.

Since this is a pilot project, which aims at showcasing energy efficiency technologies and the potential of energy efficiency in historical buildings, it was decided not to use one but many insulation materials for wall insulation. It was decided that aerogel, Vacuum insulation panels (VIP) and PIR (polyisocyanurate) insulation will be used for insulating walls of the building. All walls will be insulated from the inside. There will be 3 organic glass "frames" on the walls, which will show the insulation materials used.

Besides wall insulation from the inside, there are many energy efficiency measures that are going to be implemented in this building which include:

- Wall insulation from inside by using $50 \mathrm{~mm}$ aerogel, $100 \mathrm{~mm}$ PIR insulation or $50 \mathrm{mmVIP}$;

- Roof insulation with 300 mm PIR;

- Ground floor insulation with 200 mm PIR;

- Triple glazing with integrated shading $\left(\mathrm{U}=0,82 \mathrm{~W} / \mathrm{m}^{2} \mathrm{~K}\right)$

- Lighting system will have LED luminaries;

- Daylight using system Parans with optical fibers, where sunlight is transferred via optical fiber to rooms;

- Self-cleaning façade paint Lotusan for easier maintenance of the building;

- Heat pump for space heating;

- Mechanical ventilation with heat recovery.

\section{RESULTS AND CONCLUSIONS}

The estimated existing energy consumption for space heating of the building is 37.93 MWh per year, or 672 $\mathrm{kWh} / \mathrm{m}^{2}$ per year. Measured heat transfer coefficient for bricks is different from the calculated values, which is based on the element structure and obtained using ISO 6946-1. The calculated heat transfer coefficient is lower $\left(1.32 \mathrm{~W} / \mathrm{m}^{2} \mathrm{~K}\right)$ than measured $\left(1.48 \mathrm{~W} / \mathrm{m}^{2} \mathrm{~K}\right)$. Moisture and freeze - thaw cycles have done considerable damage to external wall structures of the Maskavas iela 8 building. The main cause of damage is poor technical condition of roof gutters. While the main reasons for masonry cracking are three: intense traffic and transport, poor foundations and groundwater fluctuations. The brick sample, which was taken from the building at Maskavas 8 showed minimum concentrations of nitrate and sulfate salt content. The building needs strengthening of wall constructions in places where cracks, loose joints and shifted bricks have developed. It is necessary to strengthen the window boxes, check the moisture barrier and prevent flaking of the joints. 
TABLE III

COMPARISON OF INSULATION MATERIALS

\begin{tabular}{|c|c|c|c|c|c|c|}
\hline Insulation material & $\begin{array}{c}\text { Thermal } \\
\text { conductivity, } \lambda \\
W /(\mathbf{m K})\end{array}$ & $\begin{array}{l}\text { Insulation } \\
\text { thickness, m }\end{array}$ & $\begin{array}{c}\text { The new } \\
\text { U-value } \\
\mathbf{W} /\left(\mathbf{m}^{2} \cdot \mathbf{K}\right) \\
\end{array}$ & $\begin{array}{c}\text { Savings of } \\
\text { U-value } \\
\mathbf{W} /\left(\mathbf{m}^{2} \cdot \mathbf{K}\right) \\
\end{array}$ & $\begin{array}{l}\text { Reduction of heat } \\
\text { consumption, } \\
\text { MWh/year }\end{array}$ & $\begin{array}{c}\text { Reduction of heat } \\
\text { consumption, } \\
\text { kWh/m² year }\end{array}$ \\
\hline Eco wool (loose cellulose fiber) & 0,037 & 0,15 & 0,21 & 1,27 & 14,37 & 255,16 \\
\hline Flax wool & 0,033 & 0,1 & 0,26 & 1,21 & 13,7 & 243,41 \\
\hline Hemp wool & 0,055 & 0,1 & 0,39 & 1,08 & 12,22 & 217,03 \\
\hline $\begin{array}{l}\text { Thermo wool by Cosmo project } \\
\text { inc. }\end{array}$ & 0,021 & 0,1 & 0,18 & 1,3 & 14,68 & 260,7 \\
\hline Aero gel mat & 0,013 & 0,04 & 0,26 & 1,11 & 12,53 & 222,51 \\
\hline Vacuum insulation panels & 0,004 & 0,06 & 0,06 & 1,42 & 16,07 & 284,86 \\
\hline
\end{tabular}

Selection of insulation materials depend on two main criteria stated for energy efficiency improvement project:

- Level of energy saved;

- Reduction of inside area.

It was calculated that after energy efficiency measures, the building's space heating energy consumption will decrease by $80 \%$, which will lead to space heating energy consumption around $130 \mathrm{kWh} / \mathrm{m}^{2}$.

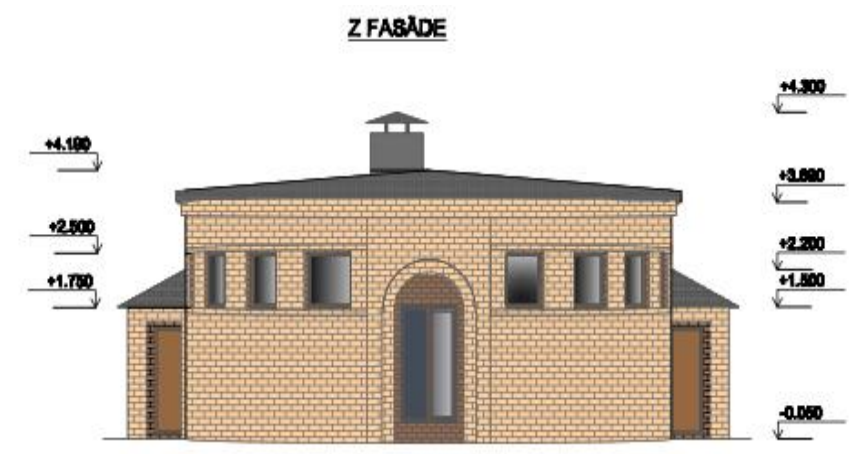

Fig. 8. Visualization of the building after renovation. Outer façade has not changed but energy consumption for heating is decreased by $80 \%$.

Energy savings by each energy efficiency measure are shown in Figure 9.

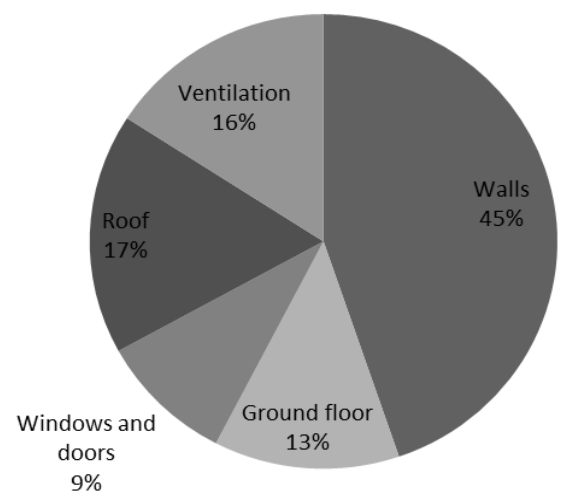

Fig.9. Energy savings by each energy efficiency measure

As seen from Figure 9, the main energy savings are predicted from wall insulation. Energy savings from other energy efficiency measures are evenly distributed.
Detailed measurements will be done after energy efficiency measures are implemented. These measurements will show the real energy savings and if there are any ill effects on the structures of this historical building after such drastic energy efficiency measures.

The results of this research can be used for similar buildings and for historic buildings overall. The results of this research show that high energy efficiency level can be reached in historic buildings without affecting the appearance of these buildings.

After refurbishment, it is planned that half of the building will serve as a public toilet (prior to renovations, the whole building was a public toilet) and the other half -- an information center about Spikkeri complex. It will be possible to visit this building to see the implemented innovative energy efficiency measures.

\section{ACKNOWLEDGEMENTS}

This research has been done within the "Co2ol Bricks" project financed by Baltic Sea Region Programme 2007-2013.

\section{REFERENCES}

1. Ascione, F., de Rossi, F., Vanoli, G.P., Energy retrofit of historical buildings: theoretical and experimental investigations for the modelling of reliable performance scenarios, Energy and Buildings 43 (2011), 19251936 http://dx.doi.org/10.1016/j.enbuild.2011.03.040

2. M.N.A. Saḷ, Ph.D, P.Eng., R.G. Demers, L.L. McSheffrey (Retired), Hygrothermal performance of a masonry wall retrofitted with interior insulation, Institute for Research in Construction, National Research Council Canada, 1200 Montreal Rd., Ottawa, Ontario, Canada K1A 0R6

3. Grinzato, E., Bison, P.G. , Marinetti, S. Monitoring of ancient buildings by the thermal method, Journal of Cultural Heritage 3 (2002), 21-29 http://dx.doi.org/10.1016/S1296-2074(02)01159-7

4. Fabbria, K., Zuppirolib, M., Ambrogioc, K. Heritage buildings and energy performance: Mapping with GIS tools, Energy and buildings 48 (2012), 137-145

5. Regulations of Cabinet of Ministers No. 495 "Regulations Regarding Latvian Construction Standard LBN 002-01 Thermotechnics of Building Envelopes" (point No. 5)

6. Regulations of Cabinet of Ministers No. 376 "Regulations regarding the Latvian Building Code LBN 003-01 "Construction Climatology"”

7. Regulations of Cabinet of Ministers No. 39 „Building energy performance calculation method".

8. ISO standard 13790:2008 "Energy performance of buildings. Calculation of energy use for space heating and cooling"

9. ISO standard 9869:1994 "Thermal insulation. Building elements. In-situ measurement of thermal resistance and thermal transmittance". 


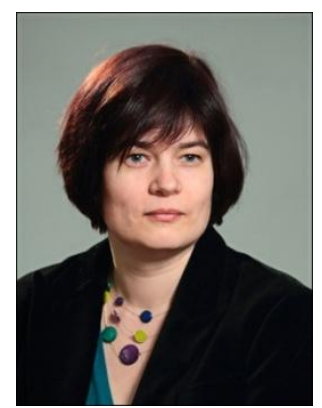

Andra Blumberga, Dr.sc.ing., professor has been part of academic staff of Institute of Environmental Protection and Energy Systems, Faculty of Energy and Electrotechnics, Riga Technical University since 2001. The main research area is end user energy efficiency. She started her professional career as energy auditor at Sloka pulp and paper factory in 1991-1993. It was followed by the six year employment as Manager of Ventilation and Refrigeration Dept. in $\mathrm{ABB}$ Latvia. From 1999-2008 Prof.Blumberga has been Director of Energy and Environmental Consulting at the company Ekodoma, where she is still acting as a consultant. She has participated in different local and international projects related to energy and environment, as well as is the author of many publications and books. She has Engineer and M.Sc. Diploma from Building Faculty, Riga Technical university and has her Ph.D. from Faculty of Energy , Riga Technical university (2001).

E-mail: andra.blumberga@rtu.lv

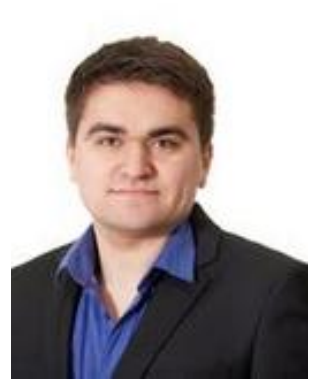

Gatis Zogla. In 2012 Gatis received a $\mathrm{PhD}$ degree in environmental engineering. His main research field is energy efficiency in buildings. $\mathrm{He}$ is currently employed in Riga Technical University in Institute of energy Systems and Environment as a Researcher and Lecturer. Currently he also works as a Energy Efficiency Consultant and Energy auditor in privatly owned company. Current research involves investigation of innovative materials and solutions to increase energy efficiency of buildings.

Gatis is the head of the board of Latvian

Energy Auditor Association.

Address: Kronvalda Blvd. 1, Riga, Latvia, LV1010

E-mail: gatis.zogla@rtu.lv

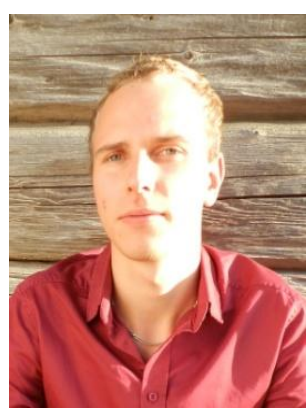

Kristaps Zvaigznitis earned bachelor's degree in Environmental Science graduating Riga Technical University Faculty of Power and Electrical Engineering (in 2014 Master's degree is expected). His thesis was "Environment's influence on bricks in historical buildings".

Since September 2011 Kristaps started a career in Riga Technical University (Latvia, Riga, Kronvalda boulev.1) as project manager assistant in field of energy performance of buildings. From July 2012 he has started to work for non-profit society the Housing and Energy Conservation Bureau as junior researcher. But since autumn 2013 Kristaps holds the position of Deputy Director. The main duties are to make research of field of existing housing stock and to raise awareness about building renovations with Energy Performance Contracting. Since May 2013 Kristaps also is working as an independent expert on a part-time job in engineering consulting company "Ekodoma" Ltd.

Address: : Kronvalda Blvd. 1, Riga, Latvia, LV1010

E-mail: kristaps.zvaigznitis@ rtu.lv

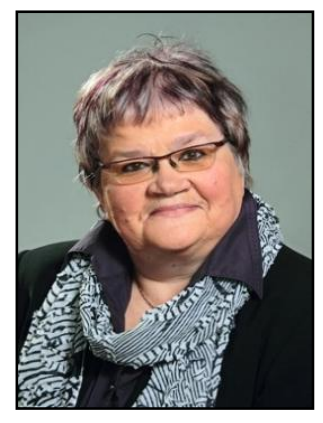

Dagnija Blumberga, Dr.hab.sc.ing. professor, Riga Technical University, Environment Protection and Heating Systems Institute. She has Thermal Engineer Diploma (1970) and two steps doctoral degree Condensing Unit" was defended in Lithuanian Energy Institute, Kaunas (1988). Doctor Habilitus Thesis "Analysis of Energy Efficiency from Environmental, Economical and Management Aspects" was prepared in Royal Institute of Technology (KTH) Stockholm (1995) and was defended in Technical University (1996)

Faculty of Energy and Electronics, Riga

Professor Dagnija Blumberga has been part of academic staff of Faculty of Energy and Electrotechnics, Riga Technical University since 1976 and director of Institute of Environmental Protection and Energy Systems since 1999.

The main research area is renewable energy resources. She has participated in different local and international projects related to energy and environment as well as is author of more than 200 publications and 14 books.

Address: Kronvalda boulevard 1, LV-1010, Riga, Latvia

Phone: +37167089908

E-mail: dagnija.blumberga@rtu.lv

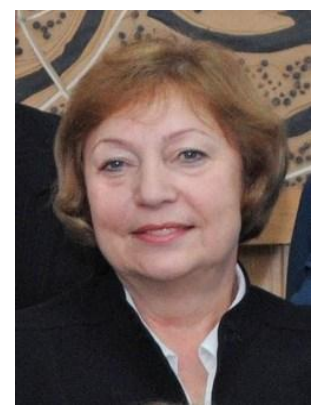

Marija Burinskiene is one of the first scientists, who started the research on sustainable development and sustainability as well as quality of life questions in Lithuania like example of post socialistic countries. Head of urban engineering department, in Vilnius Gediminas Technical University. Chief of more than 30 Comprehensive Plans of municipalities of the Lithuanian cities and regions. Chief of more than 90 scientific research projects which clients are: Ministry of Environmental, Ministry of Transportation, Lithuanian State Department of Tourism and Municipalities. Since 1997 Marija Burinskiene became director of Research Institute of Territorial Planning and the incumbent this position part time until now. Certificate of Qualification: Granted a right to be in the position of the head of the project. Type of territory planning: master, detailed and special planning of territories.

Scientific research area: urban sustainable development, planning system, interactions between transportation and town's planning, public transport. Address: Saulètekio av. 11, LT-10223, Vilnius, Lithuania E-mail: marbur@vgtu.lt 